Svetlana Kirichenko,

Jouni Henrik Juntumaa ja Markku Antero Laitinen

\title{
Komposiitti-indeksi - uusi väline käyttäjäkokemuksen arviointiin
}

\begin{abstract}
Käyttäjäkokemusindeksi ( $I_{U X}$ ) on kirjaston tarjoamien palvelujen käyttäjäkokemuksen arviointiin suunniteltu komposiitti- eli summaindeksi. Sen avulla käyttäjien tyytyväisyyttä arvioidaan laskemalla indeksiin valittujen muuttujien (asiakaskokemuksen osatekijät eli attribuutit) summa, joka muodostetaan asiakaskyselyvastausten ja asiantuntijoiden määrittelemien painokertoimien yhdistelmänä. Komposiitti-indeksin merkittävä hyöty on, että sen avulla pystytään arvioimaan useampien asiakaskokemukseen vaikuttavien tekijöiden yhteistä vaikutusta. Esittelemämme komposiitti-indeksi auttaa seuraamaan siihen valittujen määreiden yhteistä vaikutusta asiakaskokemukseen samalla kertaa.
\end{abstract}

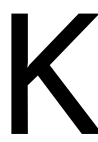

oska kirjaston käyttökokemukseen vaikuttavat monet tekijät, sitä on mahdotonta kuvata vain yhden mittarin avulla. Toisaalta usean mittarin esittäminen rinnakkain ei välttämättä anna selvää kuvaa kokonaisuudesta, eikä esim. tulosneuvotteluissa tms. tilanteessa ehkä ole mahdollisuutta perehtyä moneen mittariin samanaikaisesti. Ratkaisun saattaakin tarjota useammasta mittarista koottu komposiitti-indeksi, jonka avulla voi saada yleiskuvan kuvattavasta asiasta yhdellä vilkaisulla. Komposiitti-indeksin idea on siis laskea funktio $f R_{n} \rightarrow R$, jossa $n$ vastaa indeksiin valittujen mittareiden eli muuttujien määrä.̈.

Koska komposiitti-indeksi koostuu useasta erillisestä indikaattorista eli attribuutista (mittarista), niille voidaan haluttaessa antaa erilaiset painoarvot - kummalla on suurempi painoarvo esim. hakuportaalia arvioitaessa: tiedon löytyvyydellä vai käytön miellyttävyydellä? Saattaa siis olla tarpeen painottaa indeksin osatekijöitä eri tavoin.

Esittämämme komposiitti-indeksin määritelmä onkin yksinkertainen. Kullekin indeksiin valitulle mittarille määriteltiin normalisoitu painokerroin ja normalisoitu arvo eli käyttäjäkyselystä saatu normalisoitu mittaustulos, joka perustuu asiakkaan antamiin numeerisiin arvoihin, joiden keskiarvot normalisoitiin minimiarvon ja vaihteluvälin avulla:

Normalisoitu arvo $=$ (Keskiarvo - Minimiarvo) / Vaihteluväli 
Toinen komposiitti-indeksin osatekijä on käytettävien mittareiden (attribuuttien) "prioriteetti" eli mittareiden painokertoimet, jotka määriteltiin kirjastojen johtajille ja kehittäjille vuonna 2019 järjestetyssä työpajassa ja myös ne normalisoitiin.

Normalisoidut painokertoimet $\left(W_{R}\right)$ ja käyttäjäkyselystä saadut tulokset (Normalisoidut arvot) yhdistettiin komposiitti-indeksiksi lineaarisen funktion avulla eli kertomalla kunkin kysymyksen normalisoidut arvot vastaavalla normalisoidulla painokertoimella ja laskemalla kaikki tulokset yhteen.

Tietyn attribuutin (mittarin) painotettu arvo $\left(S_{w}\right)$ lasketaan kaavalla:

\section{$S_{w}=W_{R} \times$ Normalisoitu arvo,}

minkä jälkeen käyttäjäkokemusindeksi $\left(I_{U X}\right)$ lasketaan painotettujen arvojen summana:

$$
I_{U X}=\sum_{j=1}^{k}\left(S_{w j}\right),
$$

missä $k=$ attribuuttien lukumäärä.

Jos komposiitti-indeksin mittarit pidetään samoina, voidaan käyttäjäkokemuksen kehittymistä seuranta aikasarjassa.

\section{Soveltaminen käytäntöön}

Kansallisista Finna-käyttäjäkyselyistä 2016-202 I saatu kattava tutkimusaineisto tarjosi erinomaisen materiaalin käyttäjäkokemusindeksin laskemiseksi ja seurannaksi aikasarjana. Valitsimme indeksin muuttujiksi Finna-kyselyn Hakupalvelun arviointi -osion kysy- mykset ( $7 \mathrm{kpl}$ ), joissa vastaajat ottivat kantaa väittämiin annetulla numeroasteikolla.

Näiden seitsemän attribuutin painoarvot määriteltiin edellä mainitussa työpajassa. Kutakin osallistujaa pyydettiin antamaan attribuuteille painoarvot välillä I-ıoo. Työpajan tulosten perusteella laskimme painotusten keskiarvot ja skaalasimme ne asettamalla korkeimman keskiarvon saaneen attribuutin arvoksi roo ja suhteutimme loput järjestyksessä vastaavasti suhteuttamalla (Taulukko I).

Finna-kyselyyn vastanneet antoivat arvionsa esitettyihin väittämiin (Taulukko 1) asteikolla I-s lukuun ottamatta suositteluhalukkuutta (Net Promoter Score, NPS) ja arvosanaa koskevia kysymyksiä, joiden asteikko oli o-ro.

Lopuksi skaalasimme mittareiden painoarvot ja käyttäjäkyselyn tulosten keskiarvot ja NPS:n, ja näin saimme käyttäjäkokemusindeksin $\left(I_{U X}\right)$, joka ottaa huomioon sekä asiantuntijoitten määrittelemät painokertoimet, että Finnan käyttäjien kokemuksen palvelun tasosta.

Finna-kysely on tehty nykyisellä formaatilla vuodesta 2016 alkaen, joten käytettävissä on jo neljän kyselyn aikasarja (20I6, 20I8, 20I9 ja 202 I). Käyttäjäkokemuksen kokonaisuutena todettiin kehittyneen parempaan suuntaan koko seurannan aikana. Myös käyttäjäkokemusindeksin jokaisen osatekijän todettiin parantuneen. (Kuva 1).

Käyttäjien kokema hyöty ja kokemus tiedon paremmasta löydettävyy- 
Taulukko 1. Käyttäjäkokemusindeksin attribuutit suhteutetun painoarvon mukaisessa järjestyksessä.

destä ovat selvästi lisääntyneet, mikä lienee osaltaan vaikuttanut siihen, että myös palvelun käyttö on koettu aiempaa miellyttävämmäksi ja siten myös valmius levittää myönteistä sanaa muille (NPS) on kasvanut.

Jos komposiitti-indeksin, kuten käyttäjäkokemusindeksin, mittarit on huolellisesti valittu, yksittäisten mittarien muutokset saattavat tehdä näkyväksi kehittämistä vaativat asiakaskokemukseen vaikuttavat seikat. Aikasarjan vertailtavuuden vuoksi on luonnollisesti tarpeen pitää indeksin mittarit samoina, mutta niiden käyttökelpoisuutta on syytä myös arvioida säännöllisesti.

Komposiitti-indeksin ehdoton etu on mahdollisuus osoittaa samanaikaisesti usean tekijän vaikutus kokonaisuuteen. Se on parhaimmillaan arvioitaessa tiettyä palvelua tai kirjastoa kokonaisuutena ja se soveltuu muutosten pitkän ajan seurantaan.

Uskomme, että komposiitti-indeksin idea voidaan laajentaa myös kirjaston muihin toimintoihin, kuten esim. mittaamaan eri tekijöiden yhteistä vaikutusta kirjaston panostukseen (talous, henkilökunta, tilat).

Käyttäjäkokemusindeksi esiteltiin kolmannessatoista QQML-konferenssissa (Qualitative and Quantitative Methods in Libraries) toukokuussa $202 \mathrm{I} \mathrm{ja}$ tutkimusjulkaisu on vertaisarvioitavana julkaistavaksi Open Access -julkaisussa QQML Journal.

\begin{tabular}{|l|c|}
\hline Mittari & $\begin{array}{c}\text { Suhteutettu } \\
\text { painoarvo }\end{array}$ \\
\hline [Palvelu] on hyödyllinen & 100.00 \\
\hline Löydän etsimäni [Palvelusta] & 99.1 \\
\hline [Palvelua] on helppo käyttää & 86.9 \\
\hline [Palvelu] säästää aikaa & 81.7 \\
\hline $\begin{array}{l}\text { Kuinka todennäköisesti asteikolla } \\
\text { O-10 suosittelisit [Palvelua] muille? } \\
\text { (O = en lainkaan todennäköisesti, } \\
10=\text { erittäin todennäköisesti) (NPS) }\end{array}$ & 78.4 \\
\hline [Palvelun] käyttö on miellyttävää & 62.4 \\
\hline $\begin{array}{l}\text { Minkä arvosanan asteikolla O-10 } \\
\text { antaisit [Palvelulle]? } \\
\text { (O = alin, 10 = korkein) }\end{array}$ & 61.9 \\
\hline
\end{tabular}

Kuva 1. Finnan käyttäjäkokemusindeksi (Iux 2016-2021. (Kaikki käyttäjäryhmät.)

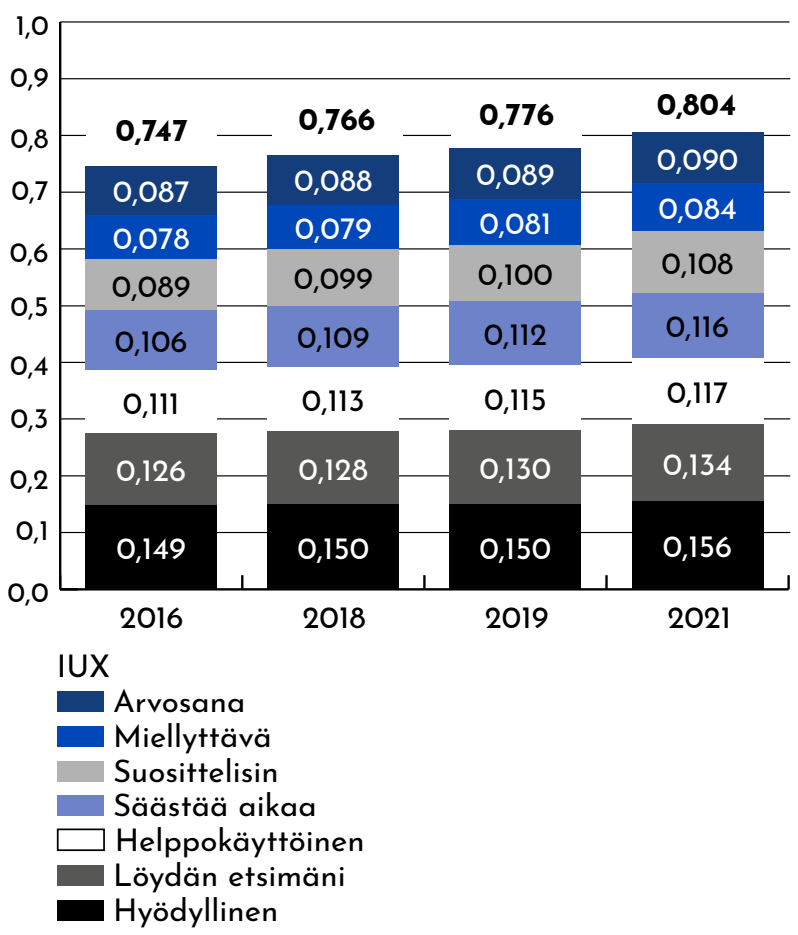

\section{Kirjoittajat}

Svetlana Kirichenko

Helsingin yliopisto svetlana.kirichenko@helsinki.fi
Jouni Henrik JuntumaA

Helsingin kaupunki, Kulttuuri ja vapaa-aika

jouni.juntumaa@hel.fi
MarkKu Antero Laitinen

Kansalliskirjasto markku.laitinen@helsinki.fi 